\title{
Swimming Against the Current of Secular Education: The Rise and Fall of Columbian Methodist College, 1892-1937
}

\author{
Eric Damer \\ Independent researcher/Burnaby Museum Researcher and Educator
}

\section{Gerald Thomson}

Independent researcher/Retired Special Education Teacher

\begin{abstract}
Jean Barman, in her book Growing Up British in British Columbia, notes that the creation of New Westminster's Columbian Methodist College was perhaps one of "the most ambitious private educational initiatives in the latter years of the [nineteenth] century" (8). When the denominational college was created, its founders believed they were creating the nucleus of the provincial university with which they would federate. However, the landscape of higher education in Canada had dramatically changed by the early 1900s. University boosters instead favoured a new government-controlled model of higher education influenced by American state universities; religion and its traditions were now incompatible with this model as the leading force in a modern university. Columbian College stood little chance of fulfilling its educational ambitions and began a struggle to survive as a denominational college, theological school, and then as a private high school. Its demise during the financial troubles of the 1930s was not unique, although many religious colleges adapted and have survived to this day.
\end{abstract}

RÉSUMÉ

Dans son livre, Growing Up British in British Columbia, Jean Barman souligne que la création du Columbian Methodist College de New Westminster, était sans doute parmi " the most ambitious private educational initiatives in the latter years of the [nineteenth] century " (8). Lorsque le collège confessionnel a vu le jour, ses fondateurs croyaient créer le noyau de l'université provinciale avec laquelle il fusionnerait. Néanmoins, le portrait de l'enseignement supérieur au Canada avait radicalement changé au début des années 1900. Sous l'influence du modèle américain, les champions de l'université ont plutôt favorisé un nouveau modèle d'enseignement supérieur sous contrôle gouvernemental; rendant le maintien du rôle central de la religion et de ses traditions incompatibles avec l'université moderne. Dans ce contexte, le Columbian College avait peu de chance de réaliser ses ambitions académiques et il a commencé à lutter pour sa survie en tant que collège confessionnel, école technique, puis comme école secondaire privé. Bien qu'il ne soit pas le seul établissement à disparaître durant la tourmente financière des années 1930, de nombreux collèges religieux ont toutefois été en mesure de s'adapter et de survivre jusqu’à ce jour. 


\section{A Failed Institution of Higher Learning}

Higher education came relatively late to British Columbia, a remote and sparsely populated British colony before joining Canada in 1871. This was generally the case across western Canada, where higher education took firm hold only after the various provinces were established. All the colonies in the East had seminaries, classical colleges, and even chartered universities before Confederation, most established by churches and intended to train clergy or groom social leaders; few, however, actually granted degrees, despite their powers to do so. University promoters in the West during the late nineteenth century knew that their meagre resources and populations could only support one degree-granting university in each province, so choosing a location and organizational model for the institution took on great importance and generated modest controversy. ${ }^{1}$

The earliest post-secondary institutions in western Canada were small, churchsponsored liberal arts and theological colleges whose promoters hoped they would have a long-lasting role in higher education, despite their sometimes narrow appeal. However, during the last decades of the nineteenth century, these small colleges grew increasingly impoverished and desperate for financial assistance beyond the meagre income provided by student fees and private subscribers. ${ }^{2}$ At the same time, new ideas about the social and educational role of the university took hold across the Englishspeaking world and elsewhere, particularly the importance of teaching science and the new science-based professions that would further material and economic development during an era of industrialization. Universities also promised social mobility to members of a tenuous middle class anxious to improve their socioeconomic standing. ${ }^{3}$ Denominational colleges, even those liberalizing through the influence of the "higher criticism," were generally not prepared to serve these new demands but nonetheless scrambled to adjust and remain relevant, using, as Paul Axelrod put it, the tools of "dogmatism, pragmatism, and innovation." As provincial governments assumed greater responsibility for higher education, many denominational colleges across Canada sought state funding or federation with a state-sponsored institution, despite losing much of their autonomy. ${ }^{4}$

One of the denominational colleges caught up in these changing social demands, Columbian Methodist College in New Westminster, British Columbia, found itself in a particularly challenging situation. Although the province's first degree-granting institution through its affiliation with Methodist Victoria College of the University of Toronto, Columbian College was largely ignored by the province's political leaders. Despite considerable efforts to be a partner in British Columbia's university movement, the college was ultimately shut out by the McBride Conservative government and its political supporters, who had no intention of including a religious college in their plans for a provincial university. A look at Columbian College's history thus underscores the desire by governments in Saskatchewan, Alberta, and especially British Columbia to create universities unfettered by church involvement and illustrates more specifically how the west coast province responded to the presence of these earlier colleges. This account joins those of Pitsula and Bumsted, who 
have provided detailed histories of Methodist Regina College and Anglican St. John's College, respectively, institutions in a similar situation during the early twentieth century. ${ }^{5}$

Historians of the University of British Columbia, including Damer and Rosengarten, Horn, Harris, and Bruneau, have noted the strong, almost heavyhanded role of government in creating and subsequently supervising the University of British Columbia despite nominally independent governance through a board of directors. ${ }^{6}$ The story of Columbian College reinforces how a few thoroughly partisan members of McBride's government propelled their singular vision of higher education to fruition. They utterly rejected an alternative and potentially viable organizational model based in religious affiliation in favour of one influenced by American state universities and the employment needs of large industries, as well as the growing demand for a new kind of technical professional in the province. McKillop's observation that the social importance of the clergy was declining in central Canada appears to ring true on the west coast, even if the decline was slow. ${ }^{7}$ Catherine Gidney has argued convincingly that religion influenced universities across Canada for many years, but Columbian College's story aptly demonstrates how religious bodies in early twentieth-century British Columbia were quite deliberately pushed into their "shadow" position. ${ }^{8}$

Columbian College also presents a case history of a failed institution of higher education, if measured against the ambitions of its supporters. Its failure arose from no particular fault internal to the institution, but from a commitment to a founding vision that grew incompatible with the evolving, secularizing social context. College founders, all affluent and influential Methodists, chose an organizational model and a location that made sense in 1891 but which later proved unsuited to the changing social, political, and economic landscape. Paul Stortz has lamented the tendency for university histories to present a triumphant account of growth and progress, asking instead for a "dispassionate and critical" account of a failed institution that carefully considers environmental influences. Charles Levi suggests that Bumsted's history of St. John's College in Manitoba provides just such an account of a "university that did not make it." However, St. John's College survives to the present day, affiliated with the University of Manitoba; Columbian College, in contrast, never did affiliate with the University of British Columbia and died during the depression of the 1930s. Levi asks, "Perhaps there are other such colleges which do not even have a building to their name... What are their stories?" Here is one such story of a vanished college, once a degree-granting institution, that survives today only as the name of a cul-de-sac in New Westminster, British Columbia.

\section{Early Public and Private Education in New Westminster}

In 1877 John Jessop, the superintendent of education for the province of British Columbia, made his annual school inspection tour of the newly-established, nondenominational free public common school system. Since their launch in 1872, public schools had faced competition from private, fee-based religious schools. Making 
specific reference to New Westminster, Jessop lamented that "several denominational and private schools in this city [are] competing for pupils with the public school," although the latter was gaining widespread support. ${ }^{10}$ Jessop should not have been surprised by the private schools in New Westminster, given its early history and social composition. Founded in 1858 by Colonel Richard Moody of the Royal Engineers as the capital of the mainland colony of British Columbia, the city was named by Queen Victoria after the city of Westminster in London, a name befitting a colonial capital. Moody, impressed by the area's natural "sublimity," charged the Royal Engineers with creating an English outpost in the wilderness, complete with wooden Victorian Gothic buildings. ${ }^{11}$ The Royal Engineers would also have been familiar with fee-based, denominational schooling, another English tradition already established on Vancouver Island nearby and afflicted by fierce rivalry. ${ }^{12}$

The Royal Engineers were soldiers building infrastructure for the colony, but they were also family men with wives and about thirty school-aged children. They encouraged local churches and private entrepreneurs to provide new educational initiatives. Anglican Reverend John Sheepshanks created a "camp school" by June 1860 for twenty-eight children from thirteen families, convincing colonial authorities to pay thirty pounds a year for the salary of a teacher, the daughter of an enlisted soldier. The rival Wesleyan (Methodist) church established a day-school that charged fifty cents a month, but it failed for lack of attendance. The Catholic Oblate Fathers founded St. Louis College in 1864 for boys, while the Sisters of St. Ann opened a girls' convent school the following year. ${ }^{13}$ Later, in 1879, the Anglicans, after creating the mainland diocese of New Westminster, launched Lorne College for boys and Columbian College (no relation) for girls. Yet during the 1880s all the Anglican school ventures collapsed and the bishop of New Westminster protested that children were sent "indiscriminately" to other schools. ${ }^{14}$ Private schools also flourished, for example, Miss Joyce's Academy for Young Ladies, which opened in 1864 and offered writing, history, geography, grammar, composition, arithmetic, French, needlework, drawing, music, and singing. ${ }^{15}$

While churches and individuals were opening their schools in the 1860s, general interest was growing in New Westminster and nearby Victoria, the capital of the Vancouver Island colony (and soon to be the capital of the united colonies), in non-sectarian common schools, partly to avoid intense church rivalries and class distinctions among schools. In New Westminster, John Robson, the Ontario-born Presbyterian editor of the British Columbian newspaper, agitated for common schools, although not without fees. ${ }^{16}$ In the summer of 1863 , the province paid for a new public school in New Westminster to accommodate up to fifty pupils. Governor Seymour inspected the school in 1865 and called it a disgrace, finding a bog on one side and "an Indian ranchiere" (encampment) on the other that was "redolent of salmon" (probably the odour from a salmon smoker). A new school site was quickly selected, and in November, the Central School opened with two teachers, one each for boys and girls. Another public common school opened in September 1863 on the grounds of the Presbyterian church, with fifteen pupils; enrolment reached twentytwo who sat end-of-term examinations in July 1864. Yet another, smaller school 
opened in neighbouring Sapperton in $1866 .{ }^{17}$ When British Columbia entered Confederation in 1871, public and political will favoured free, non-denominational schools. The following year, the Public School Act of 1872 established the province's public education system of common schools which grew quickly in the populated areas of Victoria and New Westminster. Thinking of where the school system might lead, a Victoria resident in 1871 wrote in the Colonist newspaper that a university would aid the province's prosperity and furnish the necessary "literary and professional men." 18 Of course, high schools would have to come first.

\section{The Problem of a Local High School}

By the early 1880s, New Westminster boosters decried the lack of a high school; one had already opened in Victoria in $1876 .{ }^{19}$ Local Methodists generally supported the public system but were willing to sponsor private secondary education if only to goad the province into action. ${ }^{20}$ The Methodist Church had a history of secondary and higher education beginning with John Wesley, the church's founder and a graduate of Oxford University. American Methodists had established a Wesleyan College in 1831 in Middleton, Connecticut, soon followed by other colleges and universities (some of which received huge private endowments). In Canada, Dr. Egerton Ryerson, a Methodist minister, had championed public common schools in Ontario and helped create Victoria College in Cobourg, Ontario, in 1841. In New Brunswick, Methodist Mount Allison College was granting degrees by 1863 as educated Methodists embraced science and other modern subjects, seeking the enhanced status afforded by higher education. ${ }^{21}$ In 1884, a newly unified body of Canadian Methodists upgraded Ontario's Victoria College to Victoria University and permitted Methodist secondary institutions to affiliate with it; Victoria University itself affiliated with the University of Toronto a few years later. ${ }^{22}$ When it came to establishing schools and other practical politics, New Westminster Methodists were growing in strength: the city had four Methodist churches by 1900, and by 1903, the congregations were said to include eight hundred to one thousand in a city of 6,950, making Methodist ministers prominent and influential. ${ }^{23}$ Establishing a viable secondary school was a very real possibility.

In 1881, the Reverend Ebenezer Robson, preacher at the Queen's Avenue and Sapperton Methodist churches and brother of British Columbian editor and future premier, John Robson, joined "enterprising citizens" J. S. Clute, C. G. Major, and W. J. Armstrong (Member of the Provincial Parliament) to organize a Methodistsponsored high school. ${ }^{24}$ The city of Victoria "enjoyed a free high school... while New Westminster has had nothing" wrote the local press. The first classes were held in the Queen's Avenue Methodist City Church and later in the "old public school building," financed by fees and private donations. ${ }^{25}$ The principal of the New Westminster venture, H. M. Stramberg, taught mathematics, classics, and history; a local minister taught modern languages, science, and literature; a local physician taught anatomy, physiology, and hygiene; Ebenezer Robson's sister-in-law taught voice culture and singing; and a "first class" teacher gave piano lessons. At sixty dollars a year for high 
school tuition and forty dollars a year for music instruction, the school catered to the wealthy. $^{26}$

Emboldened by the success of their high school venture, New Westminster Methodists in 1882 attempted to secure a permanent, private denominational college by registering a prospectus for a company "to establish and operate a college in New Westminster" under a board of eight trustees of whom "at least one half" would be Methodists. A number of local supporters bought shares at fifty dollars each, including businessmen, politicians, professionals, and prosperous tradesmen, who raised $\$ 2,650$ for the venture, but these efforts were soon temporarily put aside. ${ }^{27}$ By 1883 , the trustees of the Methodist high school "signified their readiness to hand over the present institution as a nucleus" for a public high school. ${ }^{28}$ In the spring of 1884 , the local press demanded the creation of a public high school, since it would attract "intending settlers of the most desirable class" to New Westminster. Perhaps because the Methodists' high school attracted pupils from across the region, a provincially supported public high school was promptly opened in the fall of 1884 , with H. M. Stramberg as its first principal. ${ }^{29}$ Having achieved its founders' goal, the Methodistsponsored venture into secondary education in New Westminster ended and a fresh initiative towards the founding of a denominational post-secondary college could begin in earnest.

\section{The Creation of Columbian College}

In 1891, the Methodist church of New Westminster and the provincial Methodist conference "again took up the question of secondary education" in the province, immediately following the collapse of legislation intended to create a provincial university. The University Act of 1891 had proposed a centralized university modeled on American state colleges that included agriculture, engineering, and other practical fields along with traditional liberal arts. The act died, however, when members of the new university senate from the mainland, particularly New Westminster and nearby Vancouver, quarreled with members from Vancouver Island and failed to make quorum at the crucial inaugural meeting. University supporters immediately looked for alternative ways to provide post-secondary education. On the mainland, support for a Methodist initiative again came from the Reverend Ebenezer Robson, whose brother was now premier and had favoured the University Act. ${ }^{30}$ The threeyear experiment with the high school provided encouragement, as did several precedents in Canadian universities. Many eastern Canadian universities had denominational roots, such as Anglican King's College, which became the University of New Brunswick, and the Baptist Canadian Literary Institute, which evolved into McMaster University. In the West lay the recent and promising example of the University of Manitoba with its four denominational teaching colleges federated with a non-denominational state-funded university that supervised student examinations, an arrangement inspired by the University of London (1836) and lauded by contemporary observers and subsequent historians. ${ }^{31}$ Furthermore, the University of Toronto had just adopted aspects of Manitoba's federated model to include Ontario's 
Methodist Victoria University (which reverted to the title "college"). ${ }^{32}$ However, this federated model was very different from the one proposed in British Columbia's 1891 University Act.

If this discrepancy concerned BC Methodists, they did not hesitate to proceed with their own plans. In 1892, the provincial Methodist conference authorized the creation of British Columbia College in New Westminster under principal Reverend R. Whittington (MA, BSc), Miss L. A. Hurlbert (MEL, Mistress of English Literature) as "lady principal" and music instructor, and three additional instructors, all with university degrees. The temporary campus facilities consisted of "several rented buildings on Ash Street." In 1893, provincial legislation incorporated the Columbian Methodist College, which immediately began teaching, although it had to wait until 1894 for the General Methodist Conference of Canada to provide financial support. ${ }^{33}$ As the first nineteen boarders and thirty-five day students enrolled, the press reported that the college "will remain in New Westminster." Most of the courses given were academic; some were in music (piano, violin) and commerce (typewriting, shorthand, bookkeeping); and some were in theology, which could lead to a degree in divinity. Although the college was co-educational, the academic and theological courses were male-dominated. Despite this initial intake, the college was losing \$213 a month and by July 1894 was seeking some $\$ 4,000$ to retire the college's debt. ${ }^{34}$

Undaunted, the college board committed itself to a permanent institution despite the lack of an endowment and the current economic recession. It was a board of considerable influence, chaired by the Reverend J. Hall (president of the provincial Methodist conference) and attracting notable members from across the region that included successful businessmen, politicians, lawyers, physicians, agricultural scientists, and church ministers. ${ }^{35}$ All were dedicated Methodists; in fact, barrister R. W. Harris was married to the daughter of pioneering Methodist coastal missionary, the Reverend Thomas Crosby. ${ }^{36}$ The board also included the Reverend Ebenezer Robson (now of Victoria) and the Reverend S. J. Thompson of Nanaimo. ${ }^{37}$ New Westminster Methodists on the board included druggist and city mayor D. S. Curtis, the city band leader, a local physician, and several successful businessmen, among other notable citizens. ${ }^{38}$ Several prominent Methodists from outside the province also sat on the board, including wholesaler J. H. White of Saint John, New Brunswick, and J. F. Betts, a Prince Albert businessman and Saskatchewan legislator. ${ }^{39}$ One distinctive board member was Professor E. Odlum, a scientist and educator who had just completed the first study of BC's forests and had recently taught at an agricultural college in Tokyo, Japan. He would send his own son to the college and later founded Terminal City Press, meanwhile amassing a fortune in real estate and insurance. ${ }^{40}$ Board members were socially significant and financially powerful men, united in their desire for a Methodist educational institution. ${ }^{41}$

Site selection occupied much of the 1893 college board meeting, as members considered several attractive offers. New Westminster had approached the provincial government to use government reserve land for the college. Burnaby municipal council next door offered a site tax-free for several years, while Vancouver's council offered a block known as South Park. Owners of Lot 27, headed by prominent New 
Westminster businessman T. J. Trapp, made an offer, politician J. W. Horne promised the college board ten acres on Westminster Avenue, the Canadian Pacific Railway offered land in Vancouver's Fairview neighbourhood, and a Mr. McKay, through an agreement with the Vancouver council, offered land in Mount Pleasant. Even Victoria and rural Chilliwack expressed interest in hosting the college by offering land for it. After thorough discussion, the board voted in favour of Vancouver and New Westminster. On the third ballot, New Westminster had fifteen supporters and Vancouver ten; settling unanimously on New Westminster, Mayor Curtis and several others formed a committee to find a permanent site. ${ }^{42}$ In 1894 , the college board purchased the H. V. Edmonds mansion on First Street at a discounted price, thanks to Edmonds' personal financial troubles and a $\$ 10,000$ church grant, mostly a gift of Hart A. Massey of Toronto. Massey, a member of a prominent and wealthy Ontario Methodist family (including several graduates from Ontario's Methodist Victoria College), also provided a low-interest loan to purchase additional land and create a campus between First and Second Streets, beside respectable Queen's Park. ${ }^{43}$

In the spring of 1894 , Principal Whittington went to Ontario where he hired four new professors to teach Hebrew and classical languages, mathematics, science, and modern languages; three held degrees from the University of Toronto. The affiliation of Columbian College with the University of Toronto through its affiliated Methodist college, Victoria College, and its graduates was now set in place, permitting students to matriculate in New Westminster and proceed seamlessly to Toronto. The local press wrote that the new professors would improve the community in their efforts to "furnish a sterling education to the youth of this Province." ${ }^{44}$ A handful of students, predominantly male, enrolled.

For these first five, foundational years, Columbian College appeared quite successful as an academic high school leading to post-secondary studies at degree-granting institutions in Toronto. By 1897, the college was small (fewer than two dozen students) but respectable and growing when Principal Whittington left office and the Reverend W. H. Easton stepped in as acting head until 1898. In January of that year, the college board found a new, permanent principal, the Reverend W. J. Sipprell, who brought ambition and energy to the educational project.

\section{Collegiate High School and University College}

Wilford James Sipprell, BA, BD (and soon to hold a Doctor of Divinity degree), a graduate (with honours) of Victoria College at the University of Toronto and medalist in philosophy and divinity, arrived in New Westminster early in 1898, after deciding quickly to leave Ontario for the west coast; his superiors in the Hamilton Conference had chosen him to head Columbian College and gave this bright, energetic, and active thirty-one-year-old man a single day to accept the position. Acting Principal W. H. Easton had been involved in some sort of minor scandal owing to his status as a bachelor, so the college board specified that they wished to appoint a married man. Sipprell proposed to his future wife, Jennie, before heading west with letters of introduction praising his scholarship and religious devotion. ${ }^{45}$ The 
new principal was somewhat more conservative than many of British Columbia's Methodists, who adopted a more liberal theology that encouraged social improvement rather than individual salvation and regeneration, but Sipprell was diplomatic with his evangelical inclinations. ${ }^{46}$

Columbian College may have been well-established in several respects, but remained financially impoverished when the Sipprells arrived. The new principal immediately arranged to pay debt and secure new suppliers, reorganizing the finances until the college had regained a sound foundation. ${ }^{47}$ Income improved considerably when the college's claim on the general education fund of the General Methodist Conference of Canada rose from 3 to 5 per cent, and the \$10,000 Massey loan was cancelled; in return, the general conference obtained the rights and powers vested in the provincial conference to oversee Columbian College. ${ }^{48}$ The Women's Educational Auxiliary of the college also provided regular gifts, often for building improvements, and Jennie Sipprell provided considerable unpaid labour. ${ }^{49}$ But it had been taxing work; Sipprell tendered his resignation a few years after arriving, citing overwork, but the college board convinced him to remain. Board members committed themselves to enhancing and expanding the college, and considered hiring fundraisers and recruiters. ${ }^{50}$ Sipprell sought stronger ties with the University of Toronto through its affiliate, Victoria College, and in 1904, Columbian's board agreed to expand educational work by adopting "the most aggressive and liberal policy compatible to sound finance." ${ }^{51}$ Enrolment rose quickly, from forty-three in 1899-1900 to over one hundred students in 1902-03.52

For eight years following Sipprell's arrival, the college strengthened its position as a leading collegiate high school in British Columbia, regularly publicizing student achievement in academics (particularly university examination scores), music, fine arts, and sports. In 1903, Columbian College earned the privilege of awarding University of Toronto Bachelor of Arts degrees (through Victoria College). In 1904, 163 students studied at Columbian College; 11 of them successfully completed first-, second-, or third-year arts degree requirements, while others completed matriculation requirements or took evening and extramural courses; 1 student completed a Bachelor of Divinity degree. Female students, typically comprising about 40 per cent of total enrolment but only about 30 per cent of the academic enrolment (they were proportionately more numerous in commercial and music studies), often won awards for scholarship but were steered into a "ladies college" course that awarded the degree of MEL (Mistress of English Literature) for completing first-year studies in arts and the degree of MLA (Mistress of Liberal Arts) for completing second-year studies. ${ }^{53}$ The college's privilege to conduct university examinations was not entirely secure, however. When the college board heard that University of Toronto officials had received letters criticizing the examinations at Columbian College, it passed resolutions affirming confidence in Sipprell and "by process of law or otherwise... [to defend] its reputation." ${ }^{54}$ By 1906, the college had awarded three University of Toronto arts degrees. ${ }^{55}$ A few students also qualified as teachers, while some graduates continued their studies elsewhere, including the McGill University medical school. ${ }^{56}$ The Sipprells regularly toured the province to recruit students and enlist the help of local ministers. 
Columbia College had a diverse, "modern" curriculum that reflected contemporary ideas about Canadian high schools, particularly in Ontario. As in Ontario, Columbian College presented itself proudly as the "downward extension of the university" rather than a continuation of elementary schools, teaching academic courses in English (composition, grammar, literature), mathematics (algebra and geometry), English and Canadian history, French, physics, chemistry, and Latin, a favourite subject at Victoria College in Ontario. ${ }^{57}$ Theology students could also study Greek and topics relevant to ministry. The college reinforced its elite image through student recitals, literary publications, and "conversaziones" held regularly for local citizens. However, like many other high schools, the college quite willingly offered commercial courses useful to many young men and, increasingly, young women. ${ }^{58}$

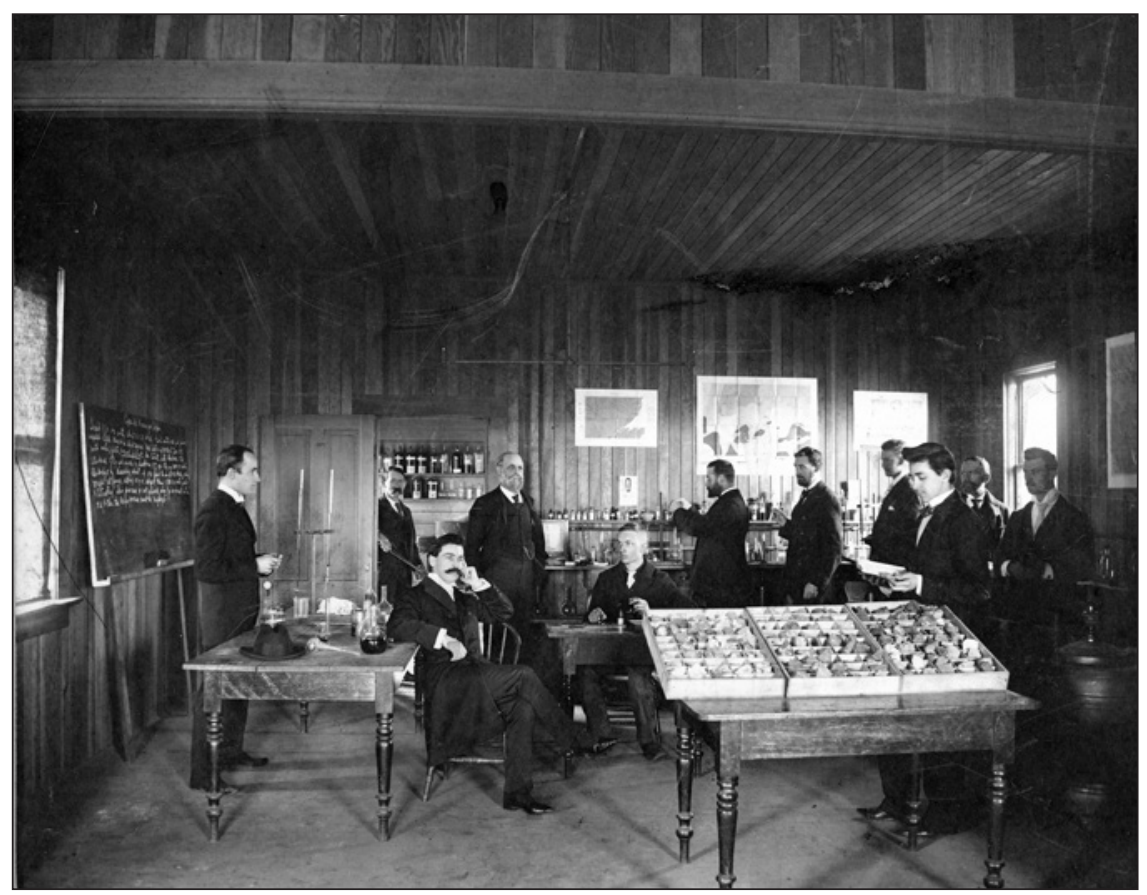

Figure 1. A science classroom at Columbian College in 1898. New Westminster Archives, Coatham family fonds, IHP2725.

Despite a largely secular curriculum, Columbian College remained committed to its religious foundation. Sipprell maintained that "the source of deepest satisfaction is in the development of a noble Christian manhood and womanhood among our students" and encouraged students to attend services at Queen's Avenue Methodist Church, although he respected parents' denominational preferences. Otherwise, the college presented itself as non-denominational and Methodist only because of financial contributions from the church. However, many of the instructors were ordained Methodist ministers. ${ }^{59}$ 


\section{Losing the Bid for the Provincial University}

Columbian College was enjoying a degree of success, but its supporters knew that change was coming. Despite government hesitation and sectional rivalries within the provincial university movement, the staff of Columbian College knew that a state-supported university would soon replace their institution; popular support for a university was growing amidst rising economic prosperity. However, college leaders welcomed the prospect and insisted that their highly respectable school should evolve into or affiliate with the provincial university, just as Methodist Alberta College after 1903 appeared to have a respected position in that region's university movement. ${ }^{60}$

However, not everyone in British Columbia shared this view. In 1899, after several years of negotiations, the Vancouver High School and College affiliated with Montreal's McGill University, an institution renowned for practical, scientific education that was allied with the powerful Canadian Pacific Railway, whose western headquarters sat in Vancouver. ${ }^{61}$ By 1903, Victoria High School and College on Vancouver Island also offered first year McGill arts courses, precipitating "a race between various Colleges and High Schools in the province" with eastern university affiliation for the coveted prize of provincial university status. Sipprell was determined not to lose out, despite other ominous signs. ${ }^{62}$ The University of Manitoba's federated model was facing challenges as the denominational colleges struggled to support teaching in scientific and professional fields, for which they had little inclination and even less money; the solution appeared to be in granting the non-denominational university additional teaching powers. ${ }^{63}$ Similarly, the University of Toronto was finding its quasi-federated organization introduced in 1887 "hopelessly flawed," resulting in a royal commission in 1905 and new legislation in 1906 to create a bicameral system of governance that would allow expansion of programs in engineering, natural sciences, medicine, and other professional areas, while reducing the influence of its denominational colleges. ${ }^{64}$ The new University of Toronto Act, influenced by the businessmen on the commission, established an organizational model resembling a corporate board that would strongly influence the new universities in western Canada, including, eventually, the University of Manitoba. ${ }^{65}$ Columbian College's vision of federation was losing popularity.

Early in 1906, Columbian College faced a major set-back when Premier Richard McBride's government moved boldly to demonstrate its preference for McGill University by creating a new, rival university-college. The government introduced a bill into the legislature to create a corporation (the "Royal Institution for the Advancement of Learning," affiliated with McGill's governing board) to negotiate with local education boards to administer existing post-secondary activities. Thus, any government grant paid to local school boards for advanced education could be turned over to the Royal Institution. A second bill proposed to give McGill University permission to establish a college in the province. Although Premier McBride, his minister of education, F. J. Fulton, and MPP Francis Carter-Cotton, a leading Vancouver newspaper owner, strongly supported the bills, a number of influential private citizens were outraged. Opponents charged that the government was rushing the bills 
through the legislature to give McGill, a private, eastern university, a monopoly on state-subsidized higher education in the province. Students, the critics argued, would not be able to transfer to their university of preference or to the alma maters of their parents. One critic decried eastern control of a British Columbia institution. ${ }^{66}$

Not surprisingly, the bill also upset supporters of Columbian College. Principal Sipprell and a college board member visited the provincial legislature in Victoria to protest, since their college, which had spent over $\$ 100,000$ on maintenance costs, had been denied university status because a state-funded institution was forthcoming. McGill was a private corporation, Sipprell argued, that should not be permitted to operate a provincial institution to the exclusion of other universities, notably the University of Toronto. Despite unsettling the usually composed Carter-Cotton during the sitting of the legislature, Sipprell lost his fight. Columbian College, CarterCotton countered, had been denied full university status because of its denominational character, a position the premier had earlier made clear. Besides, Carter-Cotton explained further, McGill, as a private corporation, could affiliate outside of its home province, while the University of Toronto, a state-funded institution, was unlikely to do so. Furthermore, McGill University had an international reputation in applied science, the area of education most needed in the province. McBride's government, the first in the province to exercise party discipline, had a slim majority, so when the dust settled, the bills had passed. Before the bills became law, Chancellor Burwash of Victoria College in Toronto advised the lieutenant-governor to withhold his signature lest the Methodist Church protest to the Dominion government; nothing appears to have come from this warning. Some observers later claimed that Columbian College had interfered unduly, prompting Sipprell to write a public defence. ${ }^{67}$

These protests did little to halt plans to convert Vancouver High School's senior classes into the McGill University College of British Columbia. Mathematician Henry Marshal Tory, McGill's representative, took note of Columbia College's protest and suggested collecting information on the money spent by the city of Vancouver and McGill University on higher education in British Columbia. ${ }^{68}$ Although Tory was an ordained Methodist minister, he nonetheless saw the future of Canadian higher education in centralized, state-funded institutions free from church or sectional disputes. ${ }^{69}$ With the new legislation in place, members of the Royal Institution established principles and policies to ensure that "McGill BC" would respond to local concerns as a non-sectarian and non-partisan college; it would be governed by local residents and admit women into arts but not applied science. Although the college did not offer a complete degree, students immediately enrolled. Theological colleges were invited to affiliate with McGill BC but the Methodist and Presbyterian churches declined, soon passing a resolution to support an independent provincial university; later, however, the Anglican church expressed interest in affiliation. ${ }^{70}$

To Principal Sipprell and Columbian College supporters, the war was not yet over; the goal to create a provincial university remained alive, and, with the location of the future university undecided, so was the possibility of college affiliation. The college, Principal Sipprell insisted, was denominational only because of church donations and a few ministers on staff. Methodism was modernizing, slowly yielding to 
new biblical scholarship and the "higher criticism," while adjusting to an increasingly urban, industrial society. ${ }^{71}$ Sipprell still believed his college was compatible with a secular state-funded university that should be located in New Westminster. ${ }^{72}$

Following the creation of McGill BC, Columbian College sought to strengthen its position. It established a School of Science and Mines, meaning a course in engineering that followed the curriculum of the new Faculty of Applied Science and Engineering of the University of Toronto, hired an instructor, and gathered new equipment for classes to begin in the fall of 1906. A few months later, the college considered sponsoring a series of lectures on "scientific farming" to emphasize its commitment to practical education and strengthen its claim as a forerunner to a state-sponsored university. The college soon added classes in electrical and mechanical engineering, and short courses in prospecting. ${ }^{73}$

The new direction initially appeared to work. Principal Sipprell announced in early 1907 that the college was operating at capacity, with over eighty students in residence and a total enrolment of over two hundred. Student fees and various grants covered expenses, although fees jumped to provide salary increases for instructors of 50 per cent (men) and 10 per cent (women). The teaching staff increased to thirteen. Construction of a new gymnasium began, and the city of New Westminster provided rebates on water rates, improvements to sidewalks and street lighting, and tax concessions to offset costs for improvements to the new science building. ${ }^{74}$ In 1908, the government finally passed legislation that created the University of British Columbia, and although it adopted centralized, bicameral governance (following the University of Toronto), the legislation still did not specify a location for the institution. Columbian College had one last chance to fulfill its ambition.

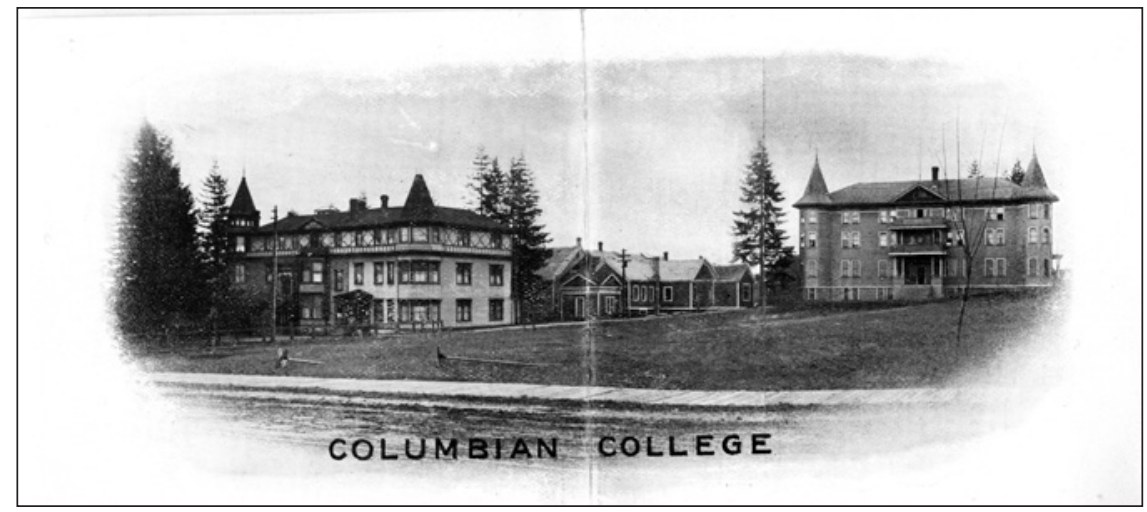

Figure 2. The Columbian College campus in 1910. New Westminster Archives, photograph collection, IHP3971.

Soon, however, the college started feeling a pinch. By 1909 costs had escalated, leaving a debt of $\$ 40,000$. The Columbian College board cancelled its engineering program (the mining program had never really begun), forcing the instructor to apply unsuccessfully for a teaching position at McGill BC. The university program was reduced, forcing students to complete their degrees elsewhere. Supporters of 
Columbian College appealed to friends, the public, and the Methodist Church for funds, obtaining a promise from Chester Massey of Toronto to provide $\$ 25,000$ if $\$ 75,000$ could be pledged locally within two years.

In the appeal for subscriptions, college supporters suddenly changed their message. They dropped references to professional careers and material progress and returned to an early emphasis on character development. D. S. Curtis, former mayor and chairman of the Columbian College board (and member of the New Westminster Board of Trade), announced that "the aim of the college is to make good men and good women out of the boys and girls of British Columbia... The necessity for a religious school will always be with us in British Columbia." The Reverend Burwash, visiting as chancellor of Victoria College, University of Toronto, said that material progress was fine, "but besides this you must develop the moral and spiritual side, for upon the moral character of your people depends the success of your future." Reverend Sipprell agreed with his colleagues and unabashedly exclaimed at a fundraiser, "Give me money, give me money, and I'll give you an institution of which you will never fail to be proud." 75 Columbian College simply could not compete with McGill BC, except in the terms now promoted by its advocates.

Part of Columbian College's disadvantage relative to McGill BC was now its location in New Westminster. Nearby Vancouver was growing quickly; in 1901, its population of some 27,000 was over four times that of New Westminster, and by 1911, Vancouver would have over 100,000 people - more than seven times the population of New Westminster. McGill BC drew from a larger pool of potential students as Vancouver became the economic capital of western Canada. ${ }^{76}$ As Vancouver's economic ambition and optimism grew, McGill BC attracted generous endowment funds from coal baron James Dunsmuir, Victoria lawyer A. C. Flumerfelt, and newspaperman Francis Carter-Cotton. Montreal's tobacco baron, Sir William MacDonald, sometime patron of McGill University, contributed a modest sum for operating costs, while local subscribers raised an additional $\$ 50,000$ by June 1909; if collected, American steel magnate Andrew Carnegie promised to contribute another $\$ 50,000 .{ }^{77} \mathrm{McG}$ ill BC also collected a small annual sum from the Vancouver School Board, and after 1907, with McBride's Conservatives now holding a solid majority, a small provincial grant to help pay its instructors. ${ }^{78}$ Partly through its applied science program, McGill BC had tied itself to leading industrialists locally and farther away. ${ }^{79}$ By 1910, McGill BC had some 150 students, all of whom were bona fide university students with educational ambition.

The last hope for Columbian College to rejoin the university movement came in spring 1910, when the provincial government created a non-partisan site-selection committee to choose the location for the provincial university. Columbian College and New Westminster boosters naturally promoted their city as the most appropriate location, but united with other lower Fraser Valley boosters to lobby against Vancouver Island. Two months later, school board chairs from several interior towns voted to locate the university near Vancouver, as did the Roman Catholic and Presbyterian churches. The choice was inevitably between Vancouver and Victoria, no matter how hard other towns might argue in favour of their industrial or pastoral 
virtues. Finally, the site commission recommended the university be placed near the economic and industrial powerhouse of Vancouver, but outside the city limits on the tip of Point Grey where there was room for agricultural experimentation; New Westminster was never a top contender. Although Premier McBride was a "native son" of New Westminster, he held a seat in the province's interior and presumably did not fear voter retaliation when he adopted the commission's recommendations. ${ }^{80}$

Soon after, an article appeared in a Vancouver journal welcoming the new University of British Columbia into "an acquaintance with the state universities of America." Written by University of Washington President Thomas F. Kane, the essay suggested the philosophical and practical links of the new British Columbia university to the western American state universities, almost celebrating the province's choice of the centralized, non-sectarian model for university education. ${ }^{81}$ Clearly the government, powerful business interests, and popular sentiment favoured a non-religious and urban provincial university more like McGill University College and less like Columbian College.

Principal Sipprell had lost his bid, although he continued to argue that the good work of Columbian College - at no expense to the public purse - made it a nat-

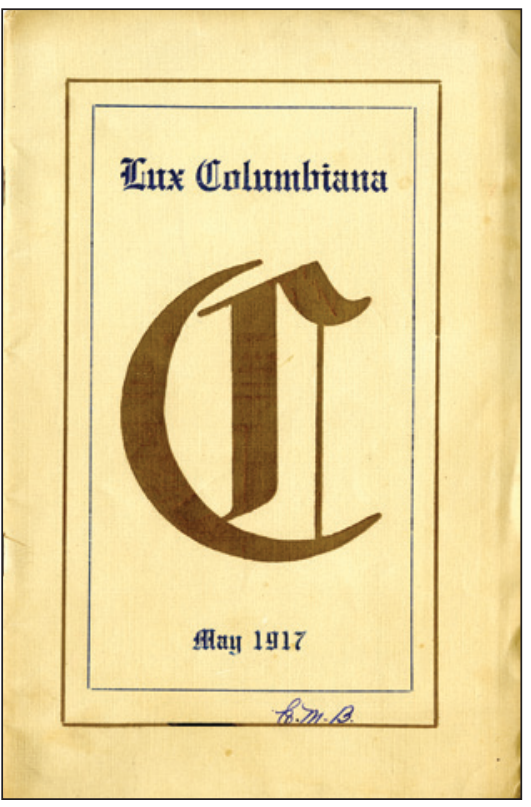

Figure 3. The May 1917 issue of the Columbian College magazine, the Lux Columbiana. It contained editorials written by staff, short literary pieces by students, reports on college activities such as drama and sports, and advertising from local businesses that supported the college. New Westminster Archives, pamphlet collection, IHP9857-0011. ural partner of the provincial university. However, Sipprell did not remain in New Westminster to manage the fate of the college. He left in 1911 with his family to study in Europe, returning to Vancouver as the minister of Mount Pleasant Methodist Church and later moving to a church in Victoria. Meanwhile, Columbian College lost another important part of its identity when the local Methodist leadership created a new theological school in 1912, Ryerson Methodist College, and prepared to build a home for it at Point Grey on the future UBC campus. Perhaps ironically, the new chairman of the Ryerson Methodist College board, influential Vancouver businessman W. H. Malkin, had once sat on the board of Columbian College. ${ }^{82}$ All was not over for the college, however; it had no debt and was busy renovating its buildings, and it had received yet another gift from the Massey family of Toronto: an endowment from Mrs. Lillian Massey Treble for all the necessary equipment to launch a new course in domestic science, a national educational movement Massey supported. ${ }^{83}$ 


\section{Decline and Experimentation in the Interwar Years}

With the university question settled, Columbian College curbed its ambitions and began working to survive in the new educational landscape. At least the collegiate high school aspect of Columbian College seemed stable; of 169 students enrolled at Columbian College in 1913-14, 39 took matriculation (university entrance) courses, down just a little from the 48 similarly enrolled in $1904 .{ }^{84}$ In 1912 , Columbian College directors asked the General Methodist Conference of Canada for permission to acquire more property in anticipation of growth in secondary education and subsequently purchased two additional properties in New Westminster. However, with McGill BC enrolling nearly three hundred students in 1913, Columbian College discontinued its university-level arts courses in 1914, the year before the University of British Columbia opened. ${ }^{85}$

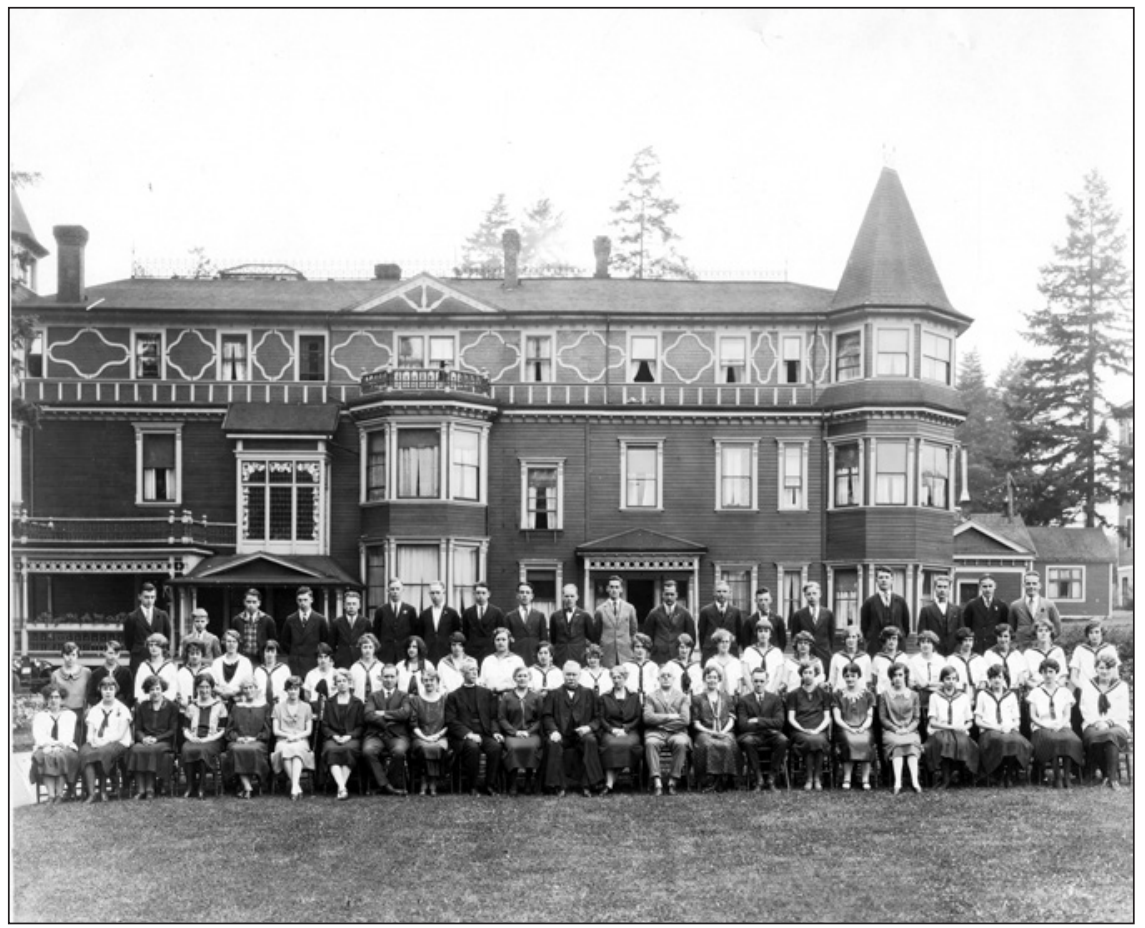

Figure 4. The staff and students of Columbian College assembled on the front lawn in the early 1920s. Such group photographs were taken annually. New Westminster Archives, photograph collection, IHP7513.

By then, Columbian's enrolment had slipped due to the economic recession of 1913 and the outbreak of war in Europe. Sipprell's successor, the Reverend Dr. A. M. Sanford (following, briefly, the Reverend A. E. Hetherington), faced a financial crisis resolved thanks to a handsome gift of $\$ 12,500$ from the Methodist Church through the Western Canada War Emergency Fund and Mrs. N. F. McCormick, 
one of Chicago's wealthiest women and a supporter of religious and educational work. Despite having only seventy-eight registered students in 1917-18, Columbian College nonetheless held its silver anniversary banquet in November 1917 with honoured guest, UBC President Frank Wesbrook (who had spoken in favour of the state-funded university model in Winnipeg a decade earlier). By the mid-1920s, the college had recovered and was "substantially free of debt" even though it no longer provided university-level education. Although in 1928 the college resumed its senior matriculation program, the equivalent of UBC's first year, it never did regain its earlier status. ${ }^{86}$

The theological school also continued for another decade, although it closed briefly during the war. Each year Columbian College admitted several students who would become active in the Methodist Church. ${ }^{87}$ Among them was Peter Kelly, a Haida lay minister who entered Columbian College in 1913 seeking respectable academic qualifications. Kelly had spent a few years at the Methodist Coqualeetza Industrial Institute, a residential school near Chilliwack, and was one of the first three Indigenous students in the province to apply for high school entrance; he was one of the only two who passed the examinations. Kelly studied for several years on his own before sitting a Columbian College entrance examination, enrolling as the first Indigenous student at the college and, after graduating, entering the ministry after a few years of teaching. ${ }^{88}$ Despite this activity, Methodist church leaders were still preparing Ryerson College in Vancouver to be their primary theological training school. Ryerson began enrolling students in 1923, leaving Columbian College strictly as a residential collegiate high school.

Principal Sanford pursued several strategies during the 1920s to attract students, keeping enrolment well above one hundred each year until his retirement in 1929. Because it had residential facilities, unlike most public high schools and even the University of British Columbia, Columbian College continued to recruit students from small towns across British Columbia. College leaders kept school fees as low as possible to minimize the financial burden, particularly for the children of Methodist ministers. Columbian also appealed to parents who were wary of Vancouver's boarding houses and preferred Columbian College's residences, where boarders observed rules prohibiting ragtime music, visits during quiet or study hours, and outside visitors without permission. ${ }^{89}$

Sanford also recruited students (and financial support) on the grounds that Columbian College provided a good moral environment. Like others, Sanford emphasized the college's moral, Christian education that developed "character" and provided "a missionary agency of very real value." He invited the Methodist Church (and the United Church, after union in 1925) to support the college "as one of the most fruitful spheres of religious endeavor"; students at Columbian College might even discover their call to the ministry. Sanford thought that the college could pioneer learner-centred pedagogies used by the church's youth groups, such as the Canadian Girls in Training and Tuxis Boys. ${ }^{90}$ The culture of Columbian College, Sanford thought, reflected the democratic attitude of the United Church in preparing for the Kingdom of God, a view supported by H. T. J. Coleman, UBC's dean of arts and 
an advocate of the new "progressive" innovations in education. Although the school officially remained non-sectarian (albeit Protestant), Columbian's directors warned that if the college were to close, other denominational schools would fill the void. ${ }^{91}$

Columbian College during the 1920s also appealed to parents of students who did not find success in the public system. Some students belonged to ethnic minorities. A student of Japanese descent enrolled as early as 1902, and between 1915 and 1925, several students with Japanese names attended Columbian College each year, many coming from the Japanese Mission in New Westminster and a few from Vancouver and even Tokyo. ${ }^{92}$ Chinese names also appeared from time to time. Other students had parents who believed them to be "at risk" of leaving high school either because of poor social influences, single-parent or transient family life, or poor health. Some parents simply preferred a religious boarding school over a public high school as a stepping stone to a better life. A few male students were a little older, working to put themselves through high school, which they had been unable to attend earlier. ${ }^{93}$

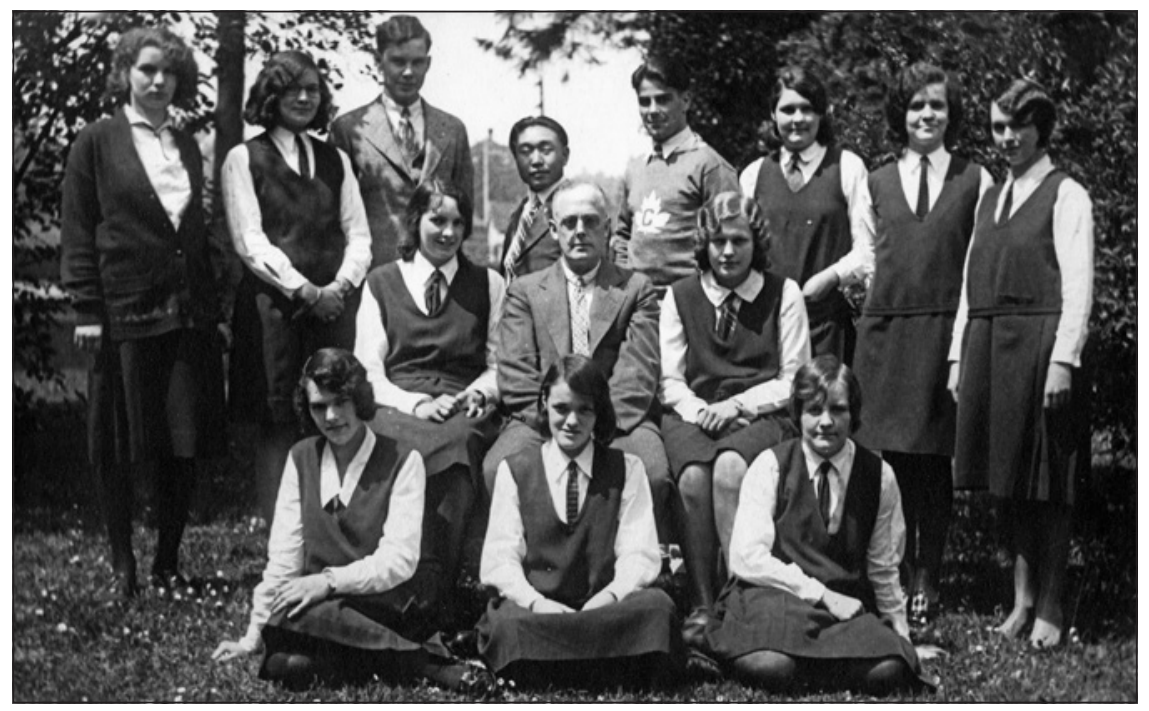

Figure 5. Students and their teacher at Columbian College in the early 1920s. Notice that the girls are wearing uniforms while the boys have jackets and ties. A Japanese student can be seen in the back row. New Westminster Archives, J. J. Johnston fonds, IHP7368-032.

The curriculum also began to emphasize music, commercial studies, and household science. In his 1921-22 report to the general conference, Sanford noted that of some 163 students, 87 were enrolled in academic courses, while 105 took courses in music. An additional 31 took the commercial program, 19 took household science, and 5 took the oratory course. Following a review by a church commission in 1922, Sanford and college board members defended their music, elocution, and household science courses, claiming that their absence in "ordinary public school" is "a very real defect." They further defended their policy on coeducation as the norm in British Columbia and elsewhere, no doubt very aware that female students now 
outnumbered male at the college. Men during the early 1900 s typically comprised over half of the student body, but following the war and through the 1920s, women were nearly twice as numerous. ${ }^{94}$ Sanford claimed that regardless of program, all students received a good grounding in liberal arts and religious education. At the close of the 1920s, however, the academic course had grown to seventy-four students, kindling optimism that university-level courses in science and mathematics might resume. ${ }^{95}$ Students may have been looking for an alternative to first year at UBC, since crowding at the university made admission more competitive. However, examination marks at Columbian College were in general decline. Sanford's successor bluntly admitted that his students "were not always the most brilliant." 96

Columbian College still relied on fees from students (particularly those in residence), subscriptions and gifts (including tax concessions from the city of New Westminster), contributions by the Women's Auxiliary, and, until 1925, a small annual subsidy from the Board of Education of the Methodist Church. Although Ryerson College now had a stronger claim on funding than Columbian, the church still provided the college with left-over contributions collected from the general conference educational fund; the church also committed funds for religious instruction. ${ }^{97}$

After church union in 1925, however, the United Church of Canada discontinued its regular subsidies, providing one-time donations and funding for religious instruction. Some national church leaders supported the Christianizing role of their affiliated high schools and decried "the effect of a purely secular state-funded education upon the national life" while the church's Board of Christian Education supported efforts to cultivate culture, spirituality, character, and other similar attributes needed "in this day of secularization." 98 However, church union had been motivated in part to help the struggling denominations save money, which remained in short supply; policy for limited funds now favoured missionary work and theological training over secondary education, a shift resembling Presbyterian more than Methodist attitudes. ${ }^{99}$ Each year, Sanford or a college board member made an appeal for a small donation of several thousand dollars, advising that without it students from less affluent families, including those of United Church ministers, would not be able to attend. Of the secondary schools across Canada affiliated with the United Church, Columbian was one of the smallest and least well endowed; although it had relatively little debt, it needed the annual subsidy. ${ }^{100}$ The precarious stability of the college was about to falter, however, with the financial collapse of the 1930s.

\section{The End of the College}

Whatever optimism college administrators proclaimed during the 1920s disappeared with the economic slump of the 1930s. Sanford tendered his resignation in 1928 to accept a teaching position at Union Theological College (formerly Ryerson College, now located on the UBC Point Grey campus), but remained another year in New Westminster until the appointment of his successor. In early 1929, Sanford welcomed the Reverend C. G. MacKenzie, writing "May his career as Principal of the College be crowned with richest success." 101 This was not to be. Enrolment at Columbian 
dropped to 70 in the fall of 1930 , although it rose to 108 by the end of the school year. More troubling, students in residence, who contributed substantially to college income, dropped from 60 to 42 in the 1930-31school year.

Matters worsened when New Westminster reduced the college's tax rebate. MacKenzie, in desperation, asked the college board whether they should sell the properties on which money was still owed. He lamented that the public considered the college to be a well-financed parochial school, rather than a provincial, ecumenical institution deserving of public support. MacKenzie sadly concluded, "the churches and individuals have largely abandoned the College." He and local church officials opposed the new policy of the United Church's Board of Education to make secondary schools self-supporting, fearing that the school would become a commercial exercise lacking a sense of spirituality "which the Church and the Kingdom stand most sorely in need." MacKenzie did not want to pander to popular school trends nor raise fees. ${ }^{102}$ Enrolment in the reinstated senior matriculation program rose to twenty-six in the fall of 1931, perhaps due to rumours of new matriculation restrictions at UBC, but student numbers declined overall. Income dropped, leaving Columbian in worse shape than most other secondary schools affiliated with the United Church. ${ }^{103}$ MacKenzie appealed to the general conference for emergency funding, and in 1932, the college asked for $\$ 25,000$ but church revenues were down and ministers' salaries took precedence, leaving only a few hundred dollars for the college. In 1932, the college board and the Women's Association campaigned to raise one dollar from every church member, without great success. In 1933, Columbian College again appealed to the presbytery for funds, but were simply "commended to the sympathy and action of the congregations." 104

MacKenzie and the board tried other initiatives to keep the college afloat. By 1930, all girls were required to study domestic science and all boys to study manual training (woodworking). Such activities kept students busy, MacKenzie reported, and boys could additionally do repairs to college buildings, although the college was decades late in embracing manual training. ${ }^{105}$ The New Westminster Presbytery considered summer sessions at the college for ministers and their wives and teachers' institutes during the Christmas holiday. ${ }^{106}$ Columbian College also tried to recruit students in grades six and seven and even opened a kindergarten. In the fall of 1932, the college reoriented itself as a residential and day school strictly for girls, again emphasizing "character ahead of knowledge" but including academic subjects up to senior matriculation (biology joined the curriculum in 1935), secretarial skills, music, art, elocution, and home economics, as well as a non-doctrinal Christianity to encourage "a happy, buoyant religion which is a power rather than a burden." Fees were kept as low as possible, but enrolment numbers stayed well below one hundred each year. In 1934-35, eighty-six students enrolled initially, but fifteen left during the year. ${ }^{107}$

In 1936, with only fifty-two students enrolled (and only sixteen in residence), the Columbian College board requested permission from the United Church to discontinue its work. An \$8,000 mortgage had been taken out against the property and several church laymen and ministers had guaranteed another $\$ 7,000$, but with an operating deficit nearing $\$ 5,000$ and $\$ 13,000$ in taxes owing to the city of New 
Westminster since 1934, college directors decided it was over; the church agreed. Easily liquidated assets were sold, and \$10,000 from the Massey endowment for domestic science reverted to Victoria College in Toronto but was later applied to the mortgage. However, the college still had some $\$ 16,000$ in debt, and at least one creditor tried to hold the United Church liable before the bills could be paid. ${ }^{108}$ A replacement co-educational residential elementary and secondary school, "The Towers," opened in the fall of 1936 under new management and survived another two years without backing from the United Church. ${ }^{109}$ Following the closure of The Towers, the buildings sat unused and deteriorating for ten years until demolished, with the property redeveloped as residential homes. As mentioned earlier, all that remains today is a cul-de-sac with a centre oval roundabout bearing the name "College Place."

\section{Conclusion}

Columbian College failed in several ways. It failed to become part of the provincial university; it failed to become the Methodist or United Church's theological school; and it failed to weather the economic crisis of the 1930s, forcing its demise. Yet it also had many successes; for some forty years, it survived to provide well-regarded secondary and even post-secondary education, as judged by contemporary opinion. Its many accomplishments can be attributed to the competence of staff, administrators, and college board members, while its failures have more to do with changes in the political climate around the nature of higher education in British Columbia.

Columbian College failed to reach its ambition as a partner of the provincial university largely because its founders chose an outmoded approach to higher education. Although the college board in the early 1890 s contained a powerful array of businessmen and professionals intent on establishing a Methodist institution, the social and political mood of the province — indeed, the country — was quickly moving away from a denominational basis for higher education. The tempo of the times favoured centralized, state-sponsored, and practical institutions that resembled business corporations, with arms-length government oversight and unfettered by church doctrine, disputes, and ministers. Colleges elsewhere in Canada by the early 1900 s were shedding their church governance to receive direct government grants. Enthusiasm for "material progress" in the sciences came to dominate higher education, especially in British Columbia, where an influx of ambitious immigrants, particularly to the Vancouver area after 1900, propelled the mandate of the provincial university towards the development of skills in engineering, agriculture, forestry, medicine, and other practical areas. Lacking private funding, Columbian College could not adapt independently and the government had no incentive to fund an additional postsecondary institution.

The growing marginalization of New Westminster also contributed to the demise of the college. The city, briefly the capital of the colony of British Columbia, competed for several decades in size and economic importance with the provincial capital of Victoria on Vancouver Island. However, the relocation of the Canadian Pacific Railway headquarters to the entrance of Burrard Inlet in 1884 almost guaranteed the 
urban dominance of Vancouver. Although Victoria remained the provincial capital, Vancouver soon led in population and economic activity. Vancouver's urbanization, expanding industrial base, and growth of its professional class went hand in hand with the demand for university education. ${ }^{110}$ New Westminster, in contrast, began a slow decline despite servicing the agricultural economy of the Fraser Valley, housing large sawmills along the Fraser River, and supporting government medical and penal institutions. Columbian College founders chose their geographical allegiance before Vancouver had decisively pulled ahead, and clung tenaciously to their location only to share in their city's slow decline. Not until 1970 did New Westminster finally acquire a public, post-secondary college, Douglas College, as part of the mass expansion of public post-secondary education in British Columbia in the 1960s. ${ }^{11}$

Finally, the decision of the Methodist Church to fund a theological school at UBC removed a crucial part of the college's identity and source of income, made worse when the United Church withdrew direct support for Columbian College. Because college leaders refused to raise fees and cater to a wealthier clientele, the college succumbed to a self-imposed financial decline that reached the bottom in the 1930s. Although British Columbia eventually had church-sponsored colleges that attained university status (Roman Catholic Notre Dame in 1950 and later Protestant Trinity Western in 1984-85), denominational colleges were very difficult to maintain financially in the early twentieth century. Provincial authorities in British Columbia and elsewhere had little interest in supporting a faith-based religious college or giving them degree-granting powers.

The story of Columbian College shows how changing economic circumstances and an evolving social-political environment - and even bad luck - proved fatal. Evidence suggests that the college had competent leadership, competent staff, and competent students. It embraced a contemporary, if not progressive, curriculum and an inclusive social vision, and it actively cultivated good relationships with its host city. It had no scandals of any consequence. Its fatal flaw was simply being what it was - a denominational college — in an increasingly secular time and place that had grown less enthusiastic for such faith-based ventures. Had the college succeeded in its ambitions, this too would have owed much to circumstances and the alignment of powerful social forces rather than the valiant efforts and clear abilities of its teachers and administrators.

\section{Notes}

1 Robin Harris, A History of Higher Education in Canada, 1663-1960 (Toronto: University of Toronto Press, 1976), 10, 113.

2 D. C. Masters, Protestant Colleges in Canada (Toronto: University of Toronto Press, 1966); Paul Axelrod, The Promise of Schooling: Education in Canada, 1800-1914 (Toronto: University of Toronto Press, 1997), 89-90.

3 R. D. Gidney and W. P. J. Millar, Professional Gentlemen: The Professions in NineteenthCentury Ontario (Toronto: University of Toronto Press, 1994), ch. 17; Paul Axelrod and John G. Reid, Youth, University, and Canadian Society (Montreal and Kingston: 
McGill-Queen's University Press, 1989), xiv-xv; David M. Cameron, More Than an Academic Question: Universities, Government and Public Policy in Canada (Halifax: Institute for Research on Public Policy, 1991), 24. For some international examples, see R. D. Anderson, Universities and Elites in Britain Since 1800 (Cambridge: Cambridge University Press, 1995); R. J. W. Selleck, The Shop: The University of Melbourne, 1850-1939 (Melbourne: Melbourne University Press, 2003); and Christopher J. Lucas, American Higher Education: A History (New York: St. Michael's Griffin, 1996).

4 Paul Axelrod, "Higher Education in Canada and the United States: Exploring the Roots of Difference," Historical Studies in Education/Revue histoire de l'éducation 7, no. 2 (1995): 141-175; Axelrod, The Promise of Schooling, 91; Paul Axelrod, Making a Middle Class: Student Life in English Canada During the Thirties (Montreal and Kingston: McGill-Queen's University Press, 1990), 10-11; Masters, Protestant Colleges in Canada, 89-90; W. L. Morton, One University: A History of the University of Manitoba, 18771952 (Toronto: McClelland \& Stewart, 1957), 70-71; J. M. Bumsted, The University of Manitoba: An Illustrated History (Winnipeg: University of Manitoba Press, 2001), 9.

5 James M. Pitsula, An Act of Faith: The Early Years of Regina College (Regina: University of Regina, Canadian Plains Research Centre, 1988); J. M. Bumsted, St. John's College: Faith and Education in Western Canada (Manitoba: University of Manitoba Press, 2006). See also Michael Hayden, Seeking a Balance: University of Saskatchewan, 19071982 (Vancouver: UBC Press, 1982); Walter. H. Johns, A History of the University of Alberta, 1908-1969 (Edmonton: University of Alberta Press, 1981); Rod Macleod, All True Things: A History of the University of Alberta, 1908-2008 (Edmonton: University of Alberta Press, 2008).

6 Eric Damer and Herbert Rosengarten, UBC: The First 100 Years (Vancouver: University of British Columbia, 2009); Eric Damer, "Teaching Teachers Revisited," in British Columbia History 44, no. 1 (2010): 37-43; Michiel Horn, "Under the Gaze of George Vancouver: The University of British Columbia and the Provincial Government, 19131939," BC Studies 83, no. 9 (1989): 29-67; R. Cole Harris, "Locating the University of British Columbia," BC Studies 32 (1976-77): 106-125; William Bruneau, A Matter of Identities: A History of the UBC Faculty Association, 1920-1990 (Vancouver: UBC Faculty Association, 1990).

7 A. B. McKillop, Matters of Mind: The University in Ontario, 1791-1951 (Toronto: University of Toronto Press, 1994), 245.

8 Catherine Gidney, A Long Eclipse: The Liberal Protestant Establishment and the Canadian University, 1920-1970 (Montreal and Kingston: McGill-Queen's University Press, 2004).

9 Paul Stortz, review of The College on the Hill by Alexander M. Ross and Terry Crowley, Canadian Historical Review 85, no. 1 (2004): 165-167; Charles Levi, review of St John's College: Faith and Education in Western Canada by J. M. Bumsted, HCanada, H-Net Reviews (November 2007).

10 Jean Barman, The West Beyond the West: A History of British Columbia (Toronto: University of Toronto Press, 1991), 103-104; Jean Barman, "The Emergence of Educational Structures in Nineteenth Century British Columbia," in Children, Teachers $\approx$ Schools in the History of British Columbia, ed. Jean Barman, Neil Sutherland, and J. Donald Wilson (Calgary: Detselig, 1995), 31.

11 Barman, The West Beyond the West, 7; R. Cole Harris, The Resettlement of British Columbia: Essays on Colonialism and Geographic Change (Vancouver: UBC Press, 1997), 82-84; Margaret A. Ormsby, British Columbia: A History (Toronto: Macmillan Press, 1958), 202.

12 Barman, "The Emergence of Educational Structures," 16-19.

13 Ibid., 16-19; Barry Mathers and Margaret McDonald, New Westminster: The Royal City (Vancouver: Keystone Press, 1958), 56-57. 
14 Jean Barman, Growing Up British in British Columbia: Boys in Private School (Vancouver: UBC Press, 1984), 7-8.

15 Alan Woodland, New Westminster: The Early Years, 1858-1898 (New Westminster: Nunaga Press, 1973), 29.

16 Barman, "The Emergence of Educational Structures," 18-19, 24-25.

17 Woodland, New Westminster, 29.

18 Damer and Rosengarten, UBC: The First 100 Years, 1.

19 Barman, The West Beyond the West, 127.

20 Barman, Growing Up British in British Columbia, 8.

21 Martin L. Friedland, The University of Toronto: A History (Toronto: University of Toronto Press, 2002), 19; John G. Reid, "Mount Allison College: The Reluctant University," Acadiensis 10, no. 1 (1980): 35-66; Axelrod, "Higher Education in Canada and the United States," 160-161, 163; Masters, Protestant Colleges in Canada, 30-37.

22 Masters, Protestant Colleges in Canada, 104-105.

23 "The Methodist Church," supplement to The Daily Columbian, December 1903, 21-22; Henderson's Greater Vancouver \& Fraser Valley Directory, 1902-1903.

24 "Collegiate and High School," The British Columbian, January 4, 1882, 3; "High School," The British Columbian, February 24, 1883, 2.

25 "High School," The British Columbian, February 24, 1883, 2.

26 "Collegiate High School Re-Opens August 30, 1882," British Columbian, August 5, 1882, 2; F. W. Howay and E. O. S. Schofield, eds., "Rev. Ebenezer Robson," in British Columbia: From the Earliest Times to the Present, vol. 4 (Vancouver: S. J. Clarke Press, 1914), 718-719. Teachers in 1882 were the Reverend W. J. Dowler, Dr. L. R. McInnes, and Mrs. D. Robson.

27 BC Archives, MS-2375, Columbian College Prospectus, 1882, 1-7; Williams' British Columbia Directory for the Years 1882-83, 207-210, 212, 215-219. Supporters included local businessmen T. R. Pearson (bookseller-stationer), F. Eickhoff (general merchandise), J. Cunningham (general merchandise), and W. Clarkson (nurseryman); tradesmen W. Turnbull (carpenter), G. Turnbull (compositor), J. Wintemute (pile driver), W. Howay (carpenter); and clerks C. Warwick and D. S. Curtis. The wealthier backers included W. J. Armstrong (lumber merchant and MPP), Alex Ewen (cannery owner), Dr. L. R. McInnes (physician), and John Robson (newspaper editor and MPP).

28 "High School," British Columbian, February 24, 1883, 2.

29 "High Schools," British Columbian, January 9, 1884, 2; F. Henry Johnson, A History of Public Education in British Columbia (Vancouver: Publications Centre, University of British Columbia), 60.

30 "The Columbian University of the Pacific Coast," supplement to The Daily Columbian, December 1903, 29; Barman, Growing Up British, 8; Damer and Rosengarten, UBC:

The First 100 Years, 4-5.

31 Cameron, More Than an Academic Question, 22; Masters, Protestant Colleges in Canada, 95-6; Morton, One University, 40.

32 Harris, A History of Higher Education in Canada, 114; Cameron, More Than an Academic Question, 22, 27; Morton, One University, 40; supplement to The Daily Columbian, December 1903, 29; BC Archives, GR-0441, February 2, 1906, Sipprell to McBride; Richard A. Johnson, "Manitoba History: The Broadway Site of the University of Manitoba, Origins and Demise," Manitoba History 51 (2006): 1; Harry W. Duckworth and Gordon Goldsborough, "Manitoba History: Science Comes to Manitoba," Manitoba History 47 (2004): 1-2.

33 "Work of Columbian College Was Re-Viewed," The Province, May 15, 1909, 5. Instructors were the Reverend W. G. Mills (BA), J. J. Ashton (BA, BD), and G. W. Boggs (MD). 
34 "Columbian College," The Province, October 5, 1893, 1. Although the first students cannot be identified, we suspect that a few were women because the college employed a lady principal from the beginning and enrolled students in stenography, typing, and music, areas that would become strongly female-dominated. In addition, the first clerical and music courses were taught by female instructors. By 1895, despite employing a male to teach gymnastics and drill, the college also employed a woman to teach calisthenics, presumably to female students. Women may also have taken academic classes. See Calendar of Victoria University, 1894 and 1895, for faculty at Columbian College.

35 Board members included merchant David Spencer, architect Francis M. Rattenbury, former MPP Noah Shakespeare, Rand family real estate developers, barrister R. W. Harris (King's Counsel), real estate-insurance tycoon William Shannon, Eburne agriculturalist J. W. Sexsmith, physician Dr. H. Wilson, Chilliwack merchant G. R. Ashwell, and Chilliwack agriculturalist A. C. Wells. C. W. Parker, ed., "David S. Spencer," in Who's Who and Why: Western Canada, Vol. 2 (Toronto: Canadian Press Association, 1912), 550; F. W. Howay and E. O. S. Schofield, eds., "F. M. Rattenbury," in British Columbia: From the Earliest Times to the Present, vol. 3 (Vancouver: S. J. Clarke Press, 1914), 705-707; J. B. Kerr, ed., "Noah Shakespeare," in Biographical Dictionary of Well Known British Columbians (Vancouver: Kerr \& Begg, 1890), 284-286; Howay and Schofield, "E. E. Rand," in British Columbia: From the Earliest Times, vol. 4, 844-847; Ibid., "R. W. Harris," 179-180; J. B. Kerr, "W. Shannon," in Biographical Dictionary, 286-287; Howay and Schofield, "J. W. Sexsmith," in British Columbia: From the Earliest Times, vol. 4, 439-440; Ibid., "Dr. H. Wilson," 1080-1081; J. B. Kerr, "G. R. Ashwell," in Biographical Dictionary, 90-91; Howay and Schofield, "G. R. Ashwell," in British Columbia: From the Earliest Times, vol. 3, 1012-1013; Howay and Schofield, "A. C. Wells," in British Columbia: From the Earliest Times, vol. 4, 957-958.

36 Howay and Schofield, "R. W. Harris," in British Columbia: From the Earliest Times, vol. 4, 179-180; Clarence Bolt, "The Conversion of the Port Simpson Tsimshian: Indian Control or Missionary Manipulation?”, BC Studies 57 (1983): 499-451.

37 Howay and Schofield, "Rev. Ebenezer Robson," in British Columbia: From the Earliest Times, vol. 4, 718-719; C. W. Parker, "Rev. S. J. Thompson," in Who's Who and Why: Western Canada, 578.

38 Board members included musicologist C. H. Watson, local physician Dr. T. Hall, hardware store and oil refinery owner James A. Cunningham, and realtor-lumbermanrailway backer C. G. Major. Howay and Schofield, "C. H. Watson," in British Columbia: From the Earliest Times, vol. 3, 282-285; J. B. Kerr, "T. Hall M.D.," in Biographical Dictionary, 176-177; Howay and Schofield, "James A. Cunningham," in British Columbia: From the Earliest Times, vol. 3, 251-252; Ibid., "D. S. Curtis," 126-129; Ibid., "C. G. Major," 156-160.

39 C. W. Parker, ed., "J. H. White," in Who' Who and Why: Canada, vols. 6 and 7 (19151916) (Toronto: International Press, 1914), 1044; C. W. Parker, ed., "J. H. Betts," in Who's Who and Why: Western Canada, 40.

40 Howay and Schofield, "Prof. E. Odlum," in British Columbia: From the Earliest Times, vol. 4, 336-342.

41 For the role of women in the Methodist Church of Canada, see Marilyn Fardig Whiteley, Canadian Methodist Women, 1766-1925: Marys, Marthas and Mothers in Israel (Waterloo: Wilfred Laurier University Press, 2005). Whiteley discusses the "supportive role" women played in the power structure of a church dominated by males. "Columbian College," British Columbian, October 5, 1893, 1.

43 Howay and Schofield, "H. V. Edmonds," in British Columbia: From the Earliest Times, vol. 3, 72-76; "The Columbian University," supplement to The Daily Columbian, December 1903, 29; "A Load Lifted," The Daily Columbian, April 17, 1903, 4; McKillop, Matters of Mind, 311. 
44 “The New Professors," British Columbian, May 8, 1894, 1. Instructors were the Reverend Professor J. J. Colter (MA, Harvard), Hebrew and classical languages; A. J. Wilson (BA, Toronto), mathematics and science; the Reverend Morley W. Peart (BA, Toronto), mathematics; and Miss M. B. Miller (BA, Toronto), calisthenics.

45 BC Archives, Sipprell Papers, MS-2058, personal and family papers.

46 Robert Kenneth Burkinshaw, Pilgrims in Lotus Land (Montreal and Kingston: McGillQueen's University Press, 1995), 25-26.

47 Ibid., 24-25; Alan Morley, Roar of the Breakers (Toronto: Ryerson Press, 1967), 87.

48 "The Methodist Church," supplement to The Daily Columbian, December 1903, 29; United Church of Canada British Columbia Conference Archives (hereafter UCCBCCA), Columbian College fonds, box 1, minute book, president's report, 1902-03.

49 UCCBCCA, Columbian College fonds, box 1-1, board of directors' minutes, November 29, 1900.

50 UCCBCCA, Columbian College fonds, box 1-13 [April 1903], "Schemes."

51 UCCBCCA, Columbian College fonds, box 1-13, November 16, 1903, report to board of directors, minutes; UCCBCCA, Columbian College fonds, box 1-13, May 20, 1904, minutes.

52 UCCBCCA, Columbian College fonds, box 1-1, minute book, November 25, 1902.

53 "Second Annual Convocation," Daily Columbian, November 20, 1903, 1; "The Columbian College: A Pacific Coast University," supplement to The New Westminster Columbian, December, 1903, 30; "141 Students," The Weekly Columbian, October 16, 1906, 8.

54 UCCBCCA, Columbian College fonds, box 1-13, March 21, 1904, minutes.

55 UCCBCCA, Columbian College fonds, box 1-13, draft correspondence [February 1906].

56 "Columbian College Honor Roll," The Daily Columbian, July 30, 1902, 1; "Columbian Convocations," The Daily Columbian, December 17, 1902, 4; "Columbian College," The Province, May 13, 1905, 4.

57 Columbian College Prospectus [1901], https://archive.org/details/cihm_83260; George S. Tomkins, A Common Countenance: Stability and Change in the Canadian Curriculum (Scarborough: Prentice-Hall, 1986), ch. 4, 135.

58 Timothy A. Dunn, "Teaching the Meaning of Work: Vocational Education in British Columbia, 1900-1929," in Shaping the Schools of the Canadian West, ed. David C. Jones, Nancy Sheehan, and Robert M. Stamp (Calgary: Detselig, 1979), 256-253; Nancy S. Jackson and Jane S. Gaskell, "White Collar Vocationalism: The Rise of Commercial Education in Ontario and British Columbia," Curriculum Inquiry 17, no. 2 (1987): 177-201; Masters, Protestant Colleges in Canada, 30-37.

59 UCCBCCA, Columbian College fonds, box 1-13, November 16, 1903, report to board of directors, minutes; UCCBCCA, Columbian College fonds, box 1-13, draft correspondence [February 1906]; Vancouver City Archives, AM54-S23-1, microfiche AM0054.013.06829, Mrs. J. P. Hodgson, The Women's Educational Club of Columbian College.

60 Johns, A History of the University of Alberta, 5-6.

61 Damer and Rosengarten, UBC: The First 100 Years, 5-6.

62 H. T. Logan, Tuum Est (Vancouver: University of British Columbia, 1958); "The University Problem and Columbian College," supplement to The Daily Columbian, December 1903, 29.

63 Morton, One University, 71; Bumsted, The University of Manitoba, 9.

64 Cameron, More Than an Academic Question, 27.

65 Friedland, The University of Toronto, 204-207; Cameron, More Than an Academic Question, 26, 29. 
66 "They Object to Control by McGill University," The Province, February 8, 1906, 1.

67 BC Archives, GR-0441, box 27-54, February 2, 1906, Sipprell to McBride, and February 7, 1906, McBride to Sipprell; "Mr. Cotton Had a Lively Day," The Province, February 9, 1906, 9; "Columbia College and the University Bill," The Province, February 14, 1906, 7; "Methodist Church Protests Against University Bill," The Province, February 23, 1906, 1.

68 University of British Columbia Archives, McGill University College of British Columbia papers (hereafter MUCBC), box 2-18, statement of principles; box 2-21, February 28, 1906, Tory to Argue.

69 Brian Coleman, "McGill British Columbia, 1899-1915," McGill Journal of Education 11, no. 2 (1976): 179-188.

70 University of British Columbia Archives, MUCBC, box 2-21, May 12, 1906, Argue to Tory; box 1-4, March 21, 1908, Pentreath to Royal Institution.

71 McKillop, Matters of Mind, 183-4, 207.

72 BC Archives, GR-0441, box 27-54, Sipprell to McBride, n.d.

73 "Adding New Chairs," The Province, June 13, 1906, 6; "Branch of YMCA for Westminster," The Province, November 14, 1906, 15; "Columbian College Is Offering Course in Science," The Province, August 5, 1908, 11; Richard White, The Skule Story (Toronto: University of Toronto Press, 2000), 54.

74 "Columbian College Makes Great Record," The Province, April 10, 1907, 11; “To Increase Pay," The Daily Columbian, April 23, 1907, 15; "Many Concessions Made to College," The Province, June 8, 1907, 13.

75 "Columbian College Must Get Support/Principal of Institution Spoke Frankly," The Province, May 14, 1909, 24.

76 Barman, The West Beyond the West, 193-194; see Table 17 for city populations, 374.

77 University of British Columbia Archives, MUCBC, box 2-12, June 19, 1909, Argue to Petersen; December 22, 1909, Betram to Peterson; box 2-19, June 17, 1909, list of subscribers.

78 University of British Columbia Archives, MUCBC, box 2-12, December 18, 1906, Tory to Peterson; March 18 1907, Argue to Peterson.

79 Eric Damer, Discovery by Design (Vancouver: Ronsdale Press, 2002), 24-25.

80 R. Cole Harris, "Locating the University of British Columbia," BC Studies 32 (197677): 106-125; University of British Columbia Archives, MUCBC, box 3-16, February 1, 1909, Education Club of Vancouver, minutes; MUCBC, box 1-12, May 30, 1910, Carter-Cotton to Argue; "Churches Join in Campaign for University," The Province, June 4, 1910, 8.

81 Thomas F. Kane, "The University of British Columbia and the University of Washington," in Schools of Old Vancouver, ed. James M. Sandison (Vancouver: Vancouver Historical Society, 1971), 44-46 (reprint).

82 UCCBCCA, Columbian College fonds, minutes, May 15, 1902; UCCBCCA, minutes of the BC Annual Conference of the Methodist Church, 1914, "Third Annual Report of Ryerson College," 423.

83 Tomkins, A Common Countenance, 119-120; "Money Provided for Columbian College," The Daily Columbian, May 31, 1910, 26; "Students Take High Standing," The Daily Columbian, August 9, 1910, 20; "Massey, Lillian Frances," in Dictionary of Canadian Biography, vol. 14 (Toronto and Laval: University of Toronto/Université Laval, 2003-), http://www.biographi.ca/en/bio/massey_lillian_frances_14E.html.

84 UCCBCCA, Columbian College fonds, box 1-13, enrolment figures for November 15 [1904]; UCCBCCA, box 460, minutes to the BC Annual Conference of the Methodist Church, Report of Columbian College (1914).

85 The Methodist Yearbook, 1912, 355; Damer and Rosengarten, UBC: The First 100 Years, 10; The United Church of Canada Yearbook 1926, Report of Columbian College, 225. 
86 “Columbian College Will Be Continued," Victoria Times, May 31, 1916, 12; United Church of Canada Yearbook 1926, Report of Columbian College, 226; UCCBCCA, Columbian College reference files, annual report, 1917-18. McCormick's gift was arranged through the Presbyterian church in Vancouver and Toronto. United Church of Canada Yearbook 1928, Report of Columbian College.

87 "College Has Fine Record," The Province, August 16, 1919, 16.

88 Morley, Roar of the Breakers, 58, 87.

89 UCCBCCA, Columbian College fonds, box 1-5, "Students in Residence at Columbian College," [1928]; UCCBCCA, Columbian College reference files, "Rules and Regulations" [1920s].

90 Margaret Prang, “'The Girl God Would Have Me Be': The Canadian Girls in Training, 1915-1939," Canadian Historical Review 66, no. 2 (1985): 154-184.

91 UCCBCCA, Columbian College fonds, box 1-4, memo to Board of Education, Methodist Church; box 1-5, "Columbian College and Educational Grant" [1928]; box 1-5, "Our Educational Policy" [1927]; United Church of Canada Yearbook 1926, Report of Columbian College, 225.

92 UCCBCCA, Columbian College fonds, box 1-12, register of students 1914-1924; UCCBCCA, box 460, minutes of the BC Conference of the Methodist Church, 1902.

93 UCCBCCA, Columbian College fonds, box 1-5, "Students in Residence at Columbian College" [1928]; "Columbian College and Educational Grant" [1928].

94 The Methodist Yearbook, 1921-22, Report of the Columbian College, 433; UCCBCCA, Columbian College fonds, box 1-5, Report of Columbia College, May 1 to October 31, 1927.

95 United Church of Canada Yearbook 1928, Report of Columbian College.

96 Damer and Rosengarten, UBC: The First 100 Years, 66; UCCBCCA, Columbian College fonds, box 1-5, report to board, October 14, 1930.

97 UCCBCCA, box 460, miscellaneous, "Allotment of Educational Apportionments" [1924]; UCCBCCA, Columbian College fonds, box 1-5, "Mr. Chairman and Members [Curtis Appeal]" [1928].

98 UCCBCCA, Columbian College fonds, box 1-5, United Church of Canada Board of Education minutes of annual general meeting, April 7, 1927; United Church of Canada Yearbook 1937, 50.

99 Pitsula, An Act of Faith, 139-140.

100 UCCBCCA, Columbian College fonds, box 1-5, Board of Education estimates, January 1 [1928]; box 1-5, college property schedule [1928]; box 1-5, registration secondary and junior colleges [1928]; box 1-5, report to board, October 14, 1930.

101 UCCBCCA, Columbian College fonds, box 1-5, report to the board, April 26, 1929.

102 UCCBCCA, Columbian College fonds, box 1-5, report to the board, October 14, 1930; New Westminster Presbytery, minutes, November 19, 1930.

103 UCCBCCA, Columbian College fonds, box 1-5, "Report of the work of Columbian College for the Year 1930-31"; Damer and Rosengarten, UBC: The First 100 Years, 83.

104 United Church of Canada Yearbook 1931, 81, and United Church of Canada Yearbook 1932, 15; UCCBCCA, Columbian College fonds, box 1-5, "Statement of Columbian College," April 1, 1934 to March 31, 1935; Columbian College reference files, March 11, 1932, Gilley to Pres. Women's Association; New Westminster Presbytery, minutes, September 13, 1933.

105 Dunn, “Teaching the Meaning of Work," 236-256.

106 New Westminster Presbytery, minutes, November 10, 1931 and September 13, 1933.

107 UCCBCCA, Columbian College fonds, box 1-5, report of the work of Columbian College for 1930-31; UCCBCCA, Columbian College fonds, box 1-5, "Statement Columbian College,” April 1, 1934 to March 31, 1935; UCCBCCA, Columbian College reference files, "Columbian College Residential and Day School for Girls" (pamphlet). 
108 United Church of Canada Yearbook 1936, 3, 61, and United Church of Canada Yearbook 1939, 6; UCCBCCA, Columbian College fonds, box 1-5, statement of Columbian College, April 1, 1934 to March 31, 1935 and "Columbian College Special Appeal" (pamphlet); "Columbian College Falls Into City's Hands for Non-Payment of Taxes," The Province, October 10, 1934, 1.

109 "Columbian College to Reopen in Fall in New Westminster," The Province, July 11, 1936, 8.

110 Patricia Roy, Vancouver: An Illustrated History (Toronto: James Lorimer, 1980), 51; Robert A. J. Macdonald, Making Vancouver (Vancouver: UBC Press, 1996), xx, 125-126; Axelrod, Making a Middle Class, 10-11; Gidney and Millar, Professional Gentlemen, ch. 17.

111 "Premier Opens New College — But Ducks Ribbon-cutting," The Columbian, November 20, 1970, 3. 